\title{
Determination of Races and Biovars of Ralstonia solanacearum causing Bacterial Wilt of Brinjal in Chhattisgarh, India
}

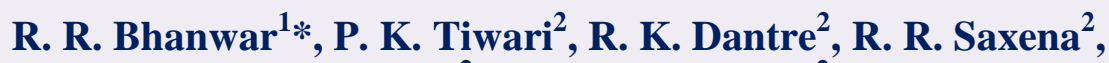 \\ A. Tiwari ${ }^{2}$ and A. Kotasthane ${ }^{2}$ \\ ${ }^{1}$ S.G.College of Agriculture and Research Station, IGKV, Jagdalpur-494005, \\ Bastar, Chhattisgarh, India \\ ${ }^{2}$ College of Agriculture, IGKV, Raipur, Chhattisgarh, India \\ *Corresponding author
}

\section{A B S T R A C T}

Keywords

Ralstonia solanacearum, race, biovar, bacterial wilt of brinjal

Article Info

Accepted: 20 May 2021 Available Online: 10 June 2021
Bacterial wilt of brinjal caused by Ralstonia solanacearum is endemic in most brinjal growing areas of Chhattisgarh state causing 40 to $80 \%$ loss in yield. Control measure requires definite information on race and biovar characteristics of the pathogen in those endemic areas. Five Ralstonia solanacearum isolates (Rs 3, Rs 7, Rs 8, Rs 11 and $R s$ 12,) of brinjal host were tested on different host plants which are host pathogenic. Under pathogenicity tests of all five $R s$ isolates on different host ranges, the brinjal, tomato, chili, potato, geranium, cucurbits and cucumber plants were infected and showed wilted symptoms except $R s 11$ in geranium. While ginger, banana, rose, soybean and sweet potato plants were not infected with any $R s$ isolates and remained healthy. According to the described in EPPO, 2004, the pattern of the infection caused by different $R s$ isolates on different host range were studied and found that the dominant $R s$ isolates in Chhattisgarh state was grouped under Race 1 (caused wide variety: Ginger, olive, chili pepper, peanut, Solanum spp., tobacco, Musa spp. (banana and plantain), peanut, Heliconia tomato and distributed in Asia, Africa, Australia, north and south America) followed by Race 3 and Race 2 with 53.84\%, $38.46 \%$ and $7.69 \%$, respectively. Therefore, dominant groups of $R s$ isolates causing bacterial wilt of brinjal belonged to race 1 and biovar III.

\section{Introduction}

Eggplant, commonly known as brinjal (Solanum melongena L.) in India, is an often cross pollinated crop and belongs to the angiospermic family solanaceae. It is a popular and principal vegetable crop widely grown in tropics and subtropics especially in Asia, Europe, Africa and America. Indian subcontinent and China are its primary centers of diversity.

India was the second largest producer of brinjal in the world with 12510000 tonnes 
production after china with 32908763 tonnes production while, India was first in area of brinjal growing countries with 733000 ha harvested area followed by China with 786266 ha area in 2017 (FAO, 2019). In India, the brinjal crop is cultivated throughout the year with annual production of 12801 '000 MT over an area of 730 ' 000 hectare in 2017-18 (Horticultural statistics at a glance, 2018). In Chhattisgarh, brinjal is an important cash crop grown over an area of 37.93 ' 000 hectare with an annual production of 705.40 '000 MT (2017-18). District Kondagaon was ranked first in area (5.30 '000 hectares) followed by district Durg (4.38 '000 hectares), while Durg district was first in production (110.32 '000 MT) followed by Kondagaon (77.75 '000 MT) in 2017-18 (Horticultural statistics at a glance 2018). There is much variation in the chemical constituents of the fruits of different types and cultivars of brinjal. Therefore, it is grown throughout the year in different parts of Bastar plateau by growing situation based cultivar.

Ralstonia solanacearum (Smith, 1896; Yabuuchi et al., 1995) causes bacterial wilt disease is one of the most destructive diseases of solanaceous crops and highly challenging worldwide. Bacterial wilt is a major problem in India and directly affects economic production of brinjal. It is also considered one of the important diseases in Chhattisgarh state especially in Bastar plateau. The wilt problem is persistent throughout the year in different parts of Bastar plateau and affects every stage of the crop. It has a wide host range remaining a major biotic limiting factor of several important crops of family solanaceae, leguminacea, several trees and herbs.

Ralstonia solanacearum is a highly species complex bacteria and has a complex of variants, variously described by several workers as groups, races, biovars, biotypes, sub-races, phylotypes and strains. The different classifications of Ralstonia solanacearum have created a considerable amount of confusion in the literature. Ralstonia solanacearum distinguished by several workers in to five bivars on the basis of carbohydrate utilization (Buddenhagen and Kelman, 1964; Denny and Hayward, 2001), five races on the basis of pathogenicity of different host range (Buddenhagen et al., 1962; Denny and Hayward, 2001; EPPO, 2004; Denny, 2006) and four phylotypes on the basis of geographical origin and genetic make-up (Fegan and Prior, 2005).

At present, there is a lot of confusion regarding the most prevalent strains of Ralstonia solanacearum in the different parts of the world. However, in India little knowledge is available about the most prevalent biovars, races and strains in various locations of India.

Races were assigned based on host range (Buddenhagen et al., 1962; Schaad et al., 2001). They used four species of the family Solanaceae (Solanum lycopersicum, Capsicum annuum, Solanum melangena and $S$. tuberosum) and one from Moracea family (Morus alba L.) for determining race of Ralstonia solanacearum. The classification of race and biovar has gained wide acceptance for subdividing Ralstonia solanacearum. On the basis of this classification system, Ralstonia solanacearum strains grouped into races according to their capability to infect different host plants. Race 1 is comprised of many strains having a wide host range and pathogenic on different solanaceous crops and weed hosts, race 2 is restricted to triploid banana and Heliconia, race 3 (potato race) affects potato, race 4 infects ginger, and race 5 is pathogenic on mulberry (He et al., 1983).

Klement et al., (1963) used pathogenicity tests for the identification of races through one month old plants were inoculated with Ralstonia solanacearum by trimming the roots 
and dipping in bacterial suspension for 30 minutes. The inoculated plants were then kept in a net house until the symptoms developed. Ralstonia solanacearum from the wilted plant was reisolated on TZC agar and colonies were compared with the original culture.

The study of the differential host plant illustrated to used different hosts for the initial separation of $X$. campestris pv. campestris isolates into races. Isolates corresponding to Kamoun's races 0, 1, 2, and 4 were identified among those tested, but isolates showing the pattern of reaction of Kamoun's race 3 were not found (Kamoun et al., 1992).

Singh et al., (2010) collected isolates of Ralstonia solanacearum from wilted solanaceous crops (potato, tomato, brinjal, chilli and capsicum) caused by $R$. solanacearum from different parts of the Northern and Eastern states of India such as Jammu and Kashmir, Himachal Pradesh, Uttarakhand, Jharkhand and West Bengal and on the basis of pathogenicity tests and Hayword's classification isolates were categorized into race 1 and biovar III.

Isolates of Ralstonia solanacearum causes bacterial rhizome rot of patumma (Circus alismatifolia) from Thailand were tested on different host range i.e. ginger, tomato, eggplant, paper and marigold for pathogenicity test and found typical wilt symptoms on different host. Patumma strains were also tested for sugar utilization test and found that three sugar alcohols oxidized but did not utilize three disaccharides in the test and they shared the same biochemical characters with strains of other hosts. Based on these characters, isolates of Ralstonia solanacearum of patumma were identified as Race 1 and biovar 4. Ralstonia solanacearum infects 29 natural hosts other than potato and tomato (Pradhanang et al., 2000). Ralstonia solanacearum has a broad host range of 450 crop species across 54 families (Wicker et al., 2009). The crop plant belonging to the solanaceous family is particularly threatened, including cultivated species such as potato, tomato, eggplant, chilii and tobacco (Hayward, 1994). Several weed host such as S.dulcamara, S.nigrum, Portulaca oleracea and Rumex dentatus (Elphinstone, 1998) and volunteer plants or (in colder climates: perennial) served as reservoir of Ralstonia solanacearum.

The major hosts of Ralstonia solanacearum worldwide were listed in Table 1 reported by different workers (Kumar et al., 2004, Kelman, 1953; Bradbury, 1986; Elphinstone, 2005) that the host range of Ralstonia solanacearum is not restricted to solanaceous crops but affected to many other plant families among broad and narrow leaf plants.

\section{Materials and Methods}

Races were assigned based on host range (Buddenhagen et al., 1962). Five isolates of Ralstonia solanacearum were multiplied in TZC medium to inoculate on differential hosts under artificial conditions. 13 plants species viz., brinjal (Solanum melongena), tomato (Lycopersicon esculentum Mill.), chilli (Capsicum frutescens), potato ( $S$. tuberosum), ginger (Z. officinale), banana (Musa accuminata), geranium (Pelargonium), rose (Rosa), soyabean (Glycine max), bottle gourd (Lagenaria siceraria), cucumber (Cucumis sativus), sweet potato (Ipomoea batatas) and mulberry (Morus alba) were used as differential hosts as method described in EPPO, 2004 (Table 2).

The seedlings were grown in a greenhouse under artificial conditions. Twenty days old seedlings of brinjal, tomato and chili were pulled out gently washed free of soil and a few tertiary roots were clipped with sterilized scissors and dipped in the bacterial culture for 
10 minutes. Tuber and rhizome of potato and ginger crops and seeds of geranium, soybean, bottle gourd and cucumber crops were dipped in the bacterial culture for 20 minutes. Stem cutting of sweet potato, rose and mulberry were dipped in the bacterial culture for 20 minutes. Thereafter, the inoculated seedlings, tubers, rhizomes, seeds and plant cuttings were transplanted to plastic bags containing slightly acidic soil. In situ inoculation of different isolates in all bags was carried out through different inoculation methods as explained in below.

\section{Direct inoculation on plant material}

Twenty to thirty days old seedlings of viz., brinjal, chili and tomato were pulled out gently and washed for free of soil. A few tertiary roots were clipped with sterilized scissors and dipped in the bacterial culture for 10 minutes. The inoculated seedlings were transplanted to plastic bags containing slightly acidic soil. The method was explained by Klement et al., (1963).

\section{Root inoculation through infested soils}

Plants were stopped watered one day before inoculation to reduce moisture in the pots. Roots of the plant were slightly injured by inserting a scalpel in the pots in order to facilitate bacterial infection. About $50 \mathrm{ml}$ of bacterial suspension was poured onto the surface of each bag. Inoculated plants were regularly watered and kept at a temperature range from 28 to $30^{\circ} \mathrm{C}$ and $80-90 \%$ relative humidity (Winstead and Kelman, 1952).

\section{Detached leaf method}

For this method terminal leaves containing 2 to 3 leaflets were selected and detached from the plants. These leaves were dipped in a conical flask or in test tubes containing bacterial suspensions for 3 to 5 minutes. This method was applied in all family of plants. Inoculated plants were observed for appearance of symptoms as explained by Winstead and Kelman (1952).

\section{Cotyledons inoculation}

Bacterial suspension was inoculated into the plant through the use of wounding done by needle puncture or carborundum to introduce the pathogen.

\section{Stem inoculation}

Bacterial suspension was introduced into the main stem of the plant with a pediatric syringe by inserting the needle gently into the vascular tissue of the main stem while carefully holding and supporting the whole plant with a hand to prevent damage.

A check was also established in the same manner but injected with sterile distilled water in place of Bacterial suspension. The same procedure was repeated after 20 days interval as described by earlier investigators (Thind and Payak, 1978; Kutama et al., 2011).

Plants similarly inoculated with sterile water served as the control. The plants were watered regularly and observations for appearance of wilt symptoms were recorded. The bacterium was re-isolated from wilted plants and compared with the original culture of Ralstonia solanacearum so as to satisfy the coach postulates.

\section{Results and Discussion}

There is no biochemical test for race identification of $R$. solanacearum caused bacterial wilt disease for a broad host range. In the present investigation on pot culture experiment, the races of $R$. solanacearum were identifying by pathogenicity test in 13 different wide host ranges as brinjal (Solanum 
melongena), tomato (Lycopersicon esculentum Mill.), chili (Capsicum frutescens), potato ( $S$. tuberosum), ginger ( $Z$. officinale), banana (Musa accuminata), geranium (Pelargonium), rose (Rosa), soybean (Glycine max), bottle gourd (Lagenaria siceraria), cucumber (Cucumis sativus), sweet potato (Ipomoea batatas) and mulberry (Morus alba) in the present study. Similar methods for pathogenicity tests were made by Wang and Berk (1997), Vicente et al., (2001), Kumar, 2006 and Nouria et al., (2009).

The result of the pathogenicity test showed in table 3 and 4, that the wilt symptoms were produced in brinjal, tomato, chili, Geranium, cucurbit and cucumber seedlings in the inoculation of $R s 3, R s 7, R s 8, R s$ 11 and $R s 12$ isolates of $R$. solanacearum, whereas potato infected with $R s \quad 3, R s \quad 8$ and $R s \quad 12$ and geranium infected with $R s 3, R s$, Rs 8 and $R s$ 12 at 75 DAT. While, none of the group of $R$. solanacearum isolates was not able to develop wilt symptoms in inoculated ginger, banana, rose, soybean and sweet potato seedlings with zero percent disease incidence. Range of percentage disease incidence in all host range were recorded in inoculation of isolates $R s 3$ with minimum $25 \%$ to maximum $60 \%$, Rs 7 with 0 to maximum $95 \%, R s 8$ with minimum 10 to maximum $100 \%$, Rs 11 with 0 to maximum $40 \%$ and $R s 12$ with minimum 15 to maximum $60 \%$ at 75 DAT. Among the all isolates of $R$. solanacearum inoculated from wilted brinjal plant, Rs 3 was more prominent to cause brinjal seedlings with $30 \%$ followed by Rs 12, Rs 8, Rs 7 and Rs 11 with 25\%, $20 \%, 15 \%$ and $10 \%$ wilt incidence respectively at 75 DAT (Table 3 and 4). Table 3and 4 showed that all five isolates of $R$. solanacearum i.e. $R s 3, R s 7, R s 8, R s 11$ and $R s 12$ were categorized into races on the basis of pathogenicity test. The brinjal, tomato, chili and potato plants were infected by all isolates of $R$. solanacearum and developed the wilt symptoms that indicate predominant races of $R$. solanacearum as race 1 followed by race 3 whereas cucurbits and cucumber plants were infected by all isolates of brinjal indicating predominant race of $R$. solanacearum as race 1. While, positive infection of geranium plants with all isolates of $R$. solanacearum except $R s 11$ were indicating predominant race as race 3. While ginger, banana, rose, soybean and sweet potato plants were not infected with any $R$. solanacearum isolates and remained healthy. In the present investigation, the pattern of the infection caused by different $R$. solanacearum isolates based on different host range as described in EPPO, 2004 were studied and found that the predominant $R$. solanacearum isolates in Bastar plateau of Chhattisgarh state was grouped under race 1 followed by race 3 and race 2 with $53.84 \%$, $38.46 \%$ and $7.69 \%$ disease incidence.

Similar studies made by Prasanna Kumar (2004) and reported that 57 isolates belonging to race 1 obtained from solanaceous and non solanaceous plants could cause infection in ginger and the 4 Ginger isolates infected solanaceous host plants but not banana and mulberry and tobacco plants. Stanford and Wolf (1917) also reported in similar studies that the strain variation of Pseudomonas solanacearum based cross inoculation method for the isolates of brinjal, tobacco, tomato and potato but found no differences among the isolates. The findings of the present study on determination of predominant races of $R$. solanacearum are also supported by Buddenhagen et al., (1962) who classified $R$. solanacearum into three races who found only one race. Race 1 infects many solanaceous plants such as brinjal, tomato, tobacco, pepper and other plants including some weeds. 
Table.1 List of major hosts of Ralstonia solanacearum

\begin{tabular}{|c|c|}
\hline Hosts & References \\
\hline Lycopersicon esculentum (tomato), Solanum tuberosum (potato) & $\begin{array}{c}\text { Sequeira, } 1998 \text {, Lopes et al. } \\
2005\end{array}$ \\
\hline \multicolumn{2}{|c|}{ Capsicum annum (sweet pepper), Solanum melongena (eggplant) } \\
\hline \multicolumn{2}{|c|}{ Nicotiana tabacum (tobacco), Arachis hypogaea (groundnut) } \\
\hline Pelargonium hortorum (geranium) & Swanson, 2007 \\
\hline Arabidopsis thaliana & Norman et al., 2009 \\
\hline Bananas and Heliconia spp & EPPO, 1999 \\
\hline Sunflower & Elphinstone, 2005 \\
\hline Pepper spp. and Morus spp & Aragaki and Quinon, 1965 \\
\hline Anacardium occidentale (cashew) & Shiomi et al., 1989 \\
\hline Annona spp. (custard apple) & Mayers and Hutton, 1987 \\
\hline Archontophoenix alexandrae (Alexandra palm) & Akiew and Hams, 1990 \\
\hline Artichokes & Aly and El ghafar, 2000 \\
\hline $\begin{array}{c}\text { Cerastium glomeratum, Drymaria cordata, Polygonum capitatum } \\
\text { and Stellaria media }\end{array}$ & Pradhanang et al., 2000 \\
\hline Solanum dulcamara (bittersweet) & Elphinstone et al., 1998 \\
\hline Urtica dioica & Wenneker et al., 1999 \\
\hline Ipomoea batatas (China) & He et al., 1983 \\
\hline Eucalyptus (Brazil, China) & Dianese et al., 1990 \\
\hline Cassava (Indonesia) & Nishiyama et al., 1980 \\
\hline Peanut (China) & $\begin{array}{l}\text { Middleton and Hayward, } \\
1990\end{array}$ \\
\hline
\end{tabular}

Table.2 Host range, Geographical distribution, Characteristics of races and their relationship with biovar of Ralstonia solanacearum (EPPO, 2004)

\begin{tabular}{|c|c|c|c|}
\hline Race & Natural host range & Geographical distribution & Biovars \\
\hline $\mathbf{1}$ & $\begin{array}{c}\text { Wide variety: Ginger, olive, chili } \\
\text { pepper, peanut, Solanum spp., and } \\
\text { tobacco }\end{array}$ & $\begin{array}{c}\text { Asia, Africa, Australia, North } \\
\text { America, and South America }\end{array}$ & $\begin{array}{c}\text { I, III, } \\
\text { IV }\end{array}$ \\
\hline $\mathbf{2}$ & $\begin{array}{c}\text { Musa spp. (banana and plantain), peanut, } \\
\text { Heliconia, and tomato }\end{array}$ & $\begin{array}{c}\text { Caribbean, Asia, Central America, } \\
\text { South America, and Hawaii }\end{array}$ & I \\
\hline $\mathbf{3}$ & $\begin{array}{c}\text { Solanaceous, and Pelargonium spp. } \\
\text { (Geranium) }\end{array}$ & $\begin{array}{c}\text { Worldwide (except Canada and } \\
\text { United States) }\end{array}$ & II \\
\hline $\mathbf{4}$ & Ginger & Australia, India, Asia, and Hawaii & III, IV \\
\hline $\mathbf{5}$ & Morus spp. (Mulberry) & china & V \\
\hline
\end{tabular}


Table.3 Pathogenicity test for determination of race of Ralstonia solanacearum $(R s)$ isolates through different host range

\begin{tabular}{|c|c|c|c|c|c|c|c|c|c|c|c|c|c|c|c|c|c|c|c|c|}
\hline \multirow[t]{3}{*}{ Name of Plants } & \multicolumn{20}{|c|}{ Bacterial wilt incidence at different days after transplanting (\%) } \\
\hline & \multicolumn{4}{|c|}{ Isolate $R s 3$} & \multicolumn{4}{|c|}{ Isolate $R s 7$} & \multicolumn{4}{|c|}{ Isolate $R s 8$} & \multicolumn{4}{|c|}{ Isolate $R s 11$} & \multicolumn{4}{|c|}{ Isolate $R s 12$} \\
\hline & 30 & 45 & 60 & 75 & 30 & 45 & 60 & 75 & 30 & 45 & 60 & 75 & 30 & 45 & 60 & 75 & 30 & 45 & 60 & 75 \\
\hline Brinjal & 0 & 0 & 18 & 30 & 0 & 0 & 12 & 15 & 0 & 0 & 16 & 20 & 0 & 0 & 0 & 10 & 10 & 10 & 25 & 25 \\
\hline Tomato & 0 & 0 & 24 & 32 & 0 & 0 & 10 & 10 & 0 & 12 & 20 & 22 & 0 & 0 & 0 & 5 & 5 & 15 & 15 & 15 \\
\hline Chilli & 0 & 20 & 32 & 38 & 0 & 0 & 0 & 14 & 0 & 12 & 30 & 36 & 0 & 0 & 0 & 0 & 0 & 20 & 20 & 20 \\
\hline Potato & 0 & 6 & 6 & 6 & 0 & 0 & 0 & 0 & 0 & 5 & 10 & 10 & 0 & 0 & 0 & 0 & 5 & 10 & 15 & 15 \\
\hline Ginger & 0 & 0 & 0 & 0 & 0 & 0 & 0 & 0 & 0 & 0 & 0 & 0 & 0 & 0 & 0 & 0 & 0 & 0 & 0 & 0 \\
\hline Banana & 0 & 0 & 0 & 0 & 0 & 0 & 0 & 0 & 0 & 0 & 0 & 0 & 0 & 0 & 0 & 0 & 0 & 0 & 0 & 0 \\
\hline Geranium & 0 & 0 & 50 & 50 & 0 & 0 & 0 & 20 & 0 & 0 & 30 & 60 & 0 & 0 & 0 & 0 & 0 & 0 & 25 & 25 \\
\hline Rose & 0 & 0 & 0 & 0 & 0 & 0 & 0 & 0 & 0 & 0 & 0 & 0 & 0 & 0 & 0 & 0 & 0 & 0 & 0 & 0 \\
\hline Soyabean & 0 & 0 & 0 & 0 & 0 & 0 & 0 & 0 & 0 & 0 & 0 & 0 & 0 & 0 & 0 & 0 & 0 & 0 & 0 & 0 \\
\hline Cucurbit & 10 & 10 & 15 & 25 & 20 & 60 & 90 & 90 & 15 & 60 & 90 & 100 & 20 & 20 & 20 & 30 & 10 & 10 & 35 & 60 \\
\hline Cucumber & 10 & 10 & 35 & 60 & 15 & 50 & 80 & 95 & 25 & 30 & 60 & 90 & 25 & 25 & 25 & 40 & 10 & 10 & 30 & 40 \\
\hline Sweet potato & 0 & 0 & 0 & 0 & 0 & 0 & 0 & 0 & 0 & 0 & 0 & 0 & 0 & 0 & 0 & 0 & 0 & 0 & 0 & 0 \\
\hline Mulberry & 0 & 0 & 0 & 0 & 0 & 0 & 0 & 0 & 0 & 0 & 0 & 0 & 0 & 0 & 0 & 0 & 0 & 0 & 0 & 0 \\
\hline
\end{tabular}


Table.4 Determination of race and biovar of different isolates of Ralstonia solanacearum (Rs) through different host range

\begin{tabular}{|c|c|c|c|c|c|c|c|}
\hline \multirow[t]{2}{*}{ Host range } & \multicolumn{5}{|c|}{ Bacterial wilt incidence at different days after transplanting (\%) } & \multirow[t]{2}{*}{ Race } & \multirow[t]{2}{*}{ Biovar } \\
\hline & Isolate $R s 3$ & Isolate $R s 7$ & Isolate $R s 8$ & Isolate $R s 11$ & Isolate $R s 12$ & & \\
\hline Brinjal & + & + & + & + & + & 1,3 & I,II,III,IV \\
\hline Tomato & + & + & + & + & + & $1,2,3$ & I,II,III,IV \\
\hline Chilli & + & + & + & + & + & 1,3 & I,II,III,IV \\
\hline Potato & + & + & + & + & + & 1,3 & I,II,III,IV \\
\hline Ginger & - & - & - & - & - & - & - \\
\hline Banana & - & - & - & - & - & - & - \\
\hline Geranium & + & + & + & - & + & 3 & II \\
\hline Rose & - & - & - & - & - & - & - \\
\hline Soyabean & - & - & - & - & - & - & - \\
\hline Cucurbit & + & + & + & + & + & 1 & I \\
\hline Cucumber & + & + & + & + & + & 1 & I \\
\hline $\begin{array}{l}\text { Sweet } \\
\text { potato }\end{array}$ & - & - & - & - & - & - & - \\
\hline Mulberry & - & - & - & - & - & - & - \\
\hline
\end{tabular}

Notes: $+=$ positive reaction (wilt infected/wilt symptoms developed), - = negative reaction (not infected/no symptoms developed)

Fig.1 Determination of races of Ralstonia solanacearum by pathogenicity test in a.Cucurbit, b.Geranium, c.Potato, d.Mulberry, e.Chili, f.Brinjal and g.Tomato plant




In addition to race 2 that causes a wilt of triploid banana (Musa spp.) and Heliconia spp., while race 3 affects potato and tomato but it is weakly virulent on other solanaceous crops. The results also support the finding of Chandrashekara et al., (2012) studied on 57 isolates and found that the ability to cause wilt in solanaceous and non solanaceous plants were designated as race 1 and biovar 3 on the basis of pathogenicity test and ELISA results. The findings of the present study are also supported by Ahmed et al., (2013) they reported that the isolates of $R$. solanacearum obtained from wilted brinjal plant inducing wilt symptom in tomato, chili and brinjal was belonging to race 1 whereas other groups of $R$. solanacearum isolates causing bacterial wilt of potato collected from three selected growing areas Bangladesh was belong to race 3 . The present results are in agreement with the results of Antony et al., (2015) that the strains of $R$. solanacearum inoculated from bacterial wilt of brinjal crop from Tamil Nadu, Southern India was identified as race I biovar after the pathogenicity test. Similarly, Anitha et al., (2018) reported that the strains of $R$. solanacearum causing bacterial wilt of brinjal were confirmed to belong to race 1 and biovar III based on symptom production on different hosts and hypersensitive response on tobacco plants. In the present investigation, the Ralstonia solanacearum bacteria causing bacterial wilt in brinjal can be included in race I followed by race III based on the findings of the previous workers.

\section{Acknowledgement}

Authors are thankful to the department of Plant Pathology, Indira Gandhi Krishi Vishwavadyalaya, Raipur, Chhattisgarh and Saheed Ghundadhur College of Agriculture and Research Station, Jagdalpur, Bastar, Chhattisgarh, India for providing necessary facilities. I would like to express my sincere thanks to my supervisor's professor Dr. P. K.
Tiwari, Indira Gandhi Krishi Vishwavadyalaya, Raipur for the constructive comments all the way from the proposal development to thesis writing.

\section{References}

Ahmed, N. N., Islam M. R., Hossain M. A., Meah M. B. and Hossain M. M. 2013. Determination of races and biovars of $R$. solanacearum causing bacterial wilt disease of potato. Journal of Agricultural Science, 5(6):86-93.

Akiew, E. and Hams, F., 1990. Archontophoenix alexandrae, a new host of Pseudomonas solanacearum in Australia. Plant Disease, 74(8).

Aly, M. M. and El-Ghafar, N. Y. A., 2000. Bacterial wilt of artichoke caused by Ralstonia solanacearum in Egypt. Plant Pathology, 49(6).

Anitha, M., Paranidharan, V. and Karthikeyan, M. 2018. Characterization of Ralstonia solanacearum (Smith) Race1, causing bacterial wilt of brinjal. Madras Agric. J., 105 (7-9): 306-312.

Antony R S, Gopalasamy G, Senthilkumar M. 2015. First report of bacterial wilt caused by Ralstonia solanacearum race I biovar I in eggplant (Solanum melongena) in Tamilnadu, southern India. Plant Dis. 99:1271.

Aragaki, M. and Quinon, V. L., 1965. Bacterial wilt of ornamental Gingers (Hedychium spp.) caused by Pseudomonas solanacearum. Plant Disease Reporter, 49(5): 378-379.

Buddenhagan, I. W., Sequeira, L. and Kelman, A. 1962. Designation of races in Pseudomonas solanacearum. Phytopathology, 52: 726.

Buddenhagen, I. and Kelman, A. 1964. Biological and physiological aspects of bacterial wilt caused by Pseudomonas solanacearum. Annual review of phytopathology. (2). 
Denny, T. P. 2006. Plant pathogenic Ralstonia species. pp 573-644 in: Plant Associated Bacteria. S. S. Gnanamanickam, ed. Springer, Dordrecht, the Netherlands.

Denny, T. P., \& Hayward, A. C. 2001. Gramnegative bacteria: Ralstonia. In N. W. Schaad, J. B. Jones, \& W. Chun (Eds.), Laboratory guide for identification of plant pathogenic bacteria (pp. 151-174, 3rd edn). APS Press, St. Paul.

Dainese-Hatt, P., Fischer, H. M., Hennecke, H., and James, P. 1999. Classifying symbiotic proteins from Bradyrhizobium japonicum into functional groups by proteome analysis of altered gene expression levels. Electrophoresis, 20(18): 3514-3520.

Elphinstone, J. G. 2005. The current bacterial wilt situation: A global overview. Pages 9-28 in: Bacterial Wilt: The Disease and the Ralstonia solanacearum Species Complex. C. Allen, P. Prior, and A. C. Hayward, eds. American Phytopathological Society Press, St. Paul, MN, U.S.A.

Elphinstone, J. G., Stanford, H., and Stead, D. E. 1998. Detection of Ralstonia solanacearum in potato tubers, Solanum dulcamara and associated irrigation water. Bacterial Wilt Disease: Molecular and Ecological Aspects. P. Prior, C. Allen, and J. G. Elphinstone, eds. Springer-Verlag, Berlin., 133-139.

EPPO/OEPP. 1999. EPPO Standards PM17/213(1). Resistance Risk Anal. Bulletin, 34: 173-178.

EPPO/OEPP (2004) EPPO Standards PM 7/21(1) Diagnostic protocol-Ralstonia solanacearum. Bulletin OEPP / EPPO Bulletin, 34: 173-178.

Fegan, M. and Prior, P., 2005. How complex is the Ralstonia solanacearum species complex. Bacterial wilt disease and the Ralstonia solanacearum species complex, 1: 449-61.

Food and Agriculture Organization (FAO). (2019). FAOSTAT Statistical Database of the United Nation Food and Agriculture Organization (FAO) statistical division. Rome.

He, L.Y., Sequiera, L., Kelman, A. 1983. Characteristics of strains of Pseudomonas solanacearum from China. Plant Dis. 67: 1357-1361.

Janse, J. D., Araluppan, F. A. X., Schans, J., Wenneker, M., and Westerhuis, W. 1998. Experiences with bacterial brown rot Ralstonia solanacearum biovar 2, race3. Springer- Verlag, Berlin, Germany, The Netherlands.

Klement, Z. 1963. Method for the rapid detection of pathogenicity of phytopathogenic pseudomonads. Nature, 199:299-300.

Kumar, A. 2006. Methods for screening ginger (Zingiber officinale Rosc.) for bacterial wilt resistance. Indian Phytopath., 59(3): 281-286.

Nouria, S., Bahara, M. and Fegan, M. 2009. Diversity of $R$. solanacearum causing potato bacterial wilt in Iran and the first record of phylotype II/biovar 2T strains outside South America. Plant Pathology, 58:243-249.

Kutama, A. S., Emechebe, A. M. and Aliyu, B. S. 2011. Field evaluation of some inoculation techniques on the incidence and severity of sorghum head smut (Sporisorium reilianum) in Nigerian Sudan savanna. Bio. Environ. Sci. J. Tropics., 8(3): 292-296.

Lopes, C. 2005. Murchadeira da Batata. Itapetininga: ABBA.

Mayers, P. E. and Hutton, D. G., 1987. Bacterial wilt, a new disease of custard apple: symptoms and etiology. Annals of applied biology, 111(1):135-141.

Middleton, K. J., and Hayward, A. C. (1990) Bacterial wilt of groundnuts. collaborative res. plan. meet., Genting 
Highlands, Malaysia, 18-19 March. Proc. ACIAR/ICRISAT 31:1-58

Nishiyama, K., Achmad, N.H., Wirtono, S. and Yamaguchi, T., 1980. Causal agents of cassava bacterial wilt in Indonesia. Contributions-Central Research Institute for Agriculture (Indonesia), (59).

Norman, D. J., Zapata, M., Gabriel D. W., Duan, Y. P., Yuen, J. M., MangravitaNovo, A. and Donahoo, R.S. 2009. Genetic diversity and host range variation of Ralstonia solanacearum strains entering North America. Phytopathology, 99: 1070-1077.

Pradhanang, P. M., J. G. Elphinstone and T. V. Fox. 2000. Identification of crops and weeds hosts of $R$. solanacearum biovar 2 in the hill of Nepal. Plant Pathology, 49: 403- 413.

Prakash, M., and Karmegam, N. 2010. Shift of total microflora in the course of vermicomposting and their association with moisture content during incubation of vermicompost In: Microbial Biotechnology (Eds.) P. Ponmurugan and V. Balakrishnan. Excel India Publishers, New Delhi,: 258-264.

Prakash, M., M. Jaikumar and Karmegam, N. 2008. Physico-chemical characteristics and fungal flora in the casts of the earthworm, Perionyx ceylanensis Mich. Reared in Polyalthea longifolia Leaf Litter. Journal of Applied Sciences Research. 4(1): 53-57.

Prasanna Kumar M. K., 2004. Molecular characterization of the strains of Ralstonia solanacearum (Yabuuchii). Ecology and integrated management of bacterial wilt of tomato Ph.D. thesis, University of Agricultural science, Bangalore, 235.

Schaad, N. W., Jones, J. B. and Chun, W. 2001. Laboratory guide for identification of plant pathogenic bacteria. Third edition, APS Press, Monnesota, USA,: 155-156.

Sequeira, L., 1998. Bacterial wilt: the missing element in international banana improvement programs. In Bacterial Wilt Disease (pp. 6-14). Springer, Berlin, Heidelberg.

Stanford, E. E. and Wolf, F. A. 1917. Studies on Bacterium solanacearum. Phytopath., 7(3): 155-165.

Swanson, J. K., Montes, L., Mejia, L. and Allen, C., 2007. Detection of latent infections of Ralstonia solanacearum race 3 biovar 2 in geranium. Plant disease, 91(7), pp.828-834.

Thind, B.S. and Payak, M.M. 1978. Evaluation of maize germplasm and estimation of losses to Erwinia stalk rot. Pl. Dis. Rep., 62: 319-23.

Vicente, J. G., Conway, J., Roberts, S. J., and Taylor, J. D. 2001. Identification and origin of Xanthomonas campestris pv. campestris races and related pathovars. Phytopathology, 91(5):492-499.

Wang, J. F. and Berk, T., 1997. Sources of resistance to bacterial wilt in Capsicum annuum. ACIAR Bacterial Wilt Newsletter, 14: 3-4.

Wenneker, M., Verdel, M. S. W., Groeneveld, R. M. W., Kempenaar, C., Van Beuningen, A.R. and Janse, J. D., 1999. Ralstonia (Pseudomonas) solanacearum race 3 (biovar 2) in surface water and natural weed hosts: First report on stinging nettle (Urtica dioica). European Journal of Plant Pathology, 105(3): 307-315.

Winstead, N. N. and Kelman, A. 1952. Inoculation Techniques for Evaluating Resistance to Pseudomonas solanacearum. Phytopathology. 42: 628-634.

Yabuuchi, E., Kosako, Y., Yano, I., Hotta, H., \& Nishiuchi, Y. 1995. Transfer of two Burkholderia and an Alcaligenes species to Ralstonia Gen. Nov.: 
Proposal of Ralstonia pickettii (Ralston, Palleroni and Doudoroff 1973) Comb Nov., Ralstonia solanacearum (Smith 1896) Comb. Nov. and Ralstonia eutropha (Davis 1969) Comb. Nov. Microbiology and Immunology, 39(11): 897-904.

Suthar, S., 2007. Vermicomposting potential of Perionyx sansibaricus (Perrier) in different waste materials. Bioresour. Technol. 98: 1231-1237.

Prakash, M., and Karmegam, N. 2010. Vermistabilization of pressmud using Perionyx ceylanensis Mich. Bioresource Technology. 101 (21): 8464-8468.

Prakash, M., and Karmegam, N. 2010. Dynamics of nutrients and microflora during vermicomposting of mango leaf litter (Mangifera indica L.) in presence of Perionyx ceylanensis Mich. International Journal of Global Environmental Issues.10(3/4): 339353.

Prakash, M., and Karmegam, N. 2010. Shift of total microflora in the course of vermicomposting and their association with moisture content during incubation of vermicompost In: Microbial Biotechnology (Eds.) P. Ponmurugan and V. Balakrishnan. Excel India Publishers, New Delhi. 258-264.

Prakash, M., M. Jaikumar and Karmegam, N. 2008.Physico-chemical Characteristics and Fungal Flora in the Casts of the Earthworm, Perionyx ceylanensis Mich. Reared in Polyalthea longifolia Leaf Litter. Journal of Applied Sciences Research, 4(1): 53-57.

Ravikumar, M., K. R. Sridhar, T. Sivakumar, K. S. Karamchand, N. Sivakumar and Vellaiyan, R. 2009. Diversity of filamentous fungi on coastal woody debris after tsunami on the southeast coast of India. Czech Mycol. 61(1): $107-115$.

Sivakumar, T. 2007. Biodiversity and Biotechnological potentials of fungi from Muthupet Mangroves, Tamil Nadu, India. Ph.D. Thesis, Bharathidasan University, Thiruchirappalli, India.

Edwards, C. A., and Arancon, N. Q. 2004. The use of earthworms in the breakdown of organic wastes to produce vermicomposts and animal feed protein. In: Edwards, C.A. (Ed.), Earthworm Ecology, second ed. CRC Press, Boca Raton., 345-438.

Horticultural Statistics at a Glance. 2018. Ministry of Agriculture \& Farmers' Welfare Department of Agriculture, Cooperation \& Farmers' Welfare, Govt. of India.

Smith, E. F. 1896. A Bacterial Disease of the Tomato, Eggplant, and Irish potato (Bacillus solanacearum nov. sp.). U.S. Department of Agriculture, Washington, DC.

\section{How to cite this article:}

Bhanwar, R. R., P. K. Tiwari, R. K. Dantre, R. R. Saxena, A. Tiwari and Kotasthane, A. 2021. Determination of Races and Biovars of Ralstonia solanacearum causing Bacterial Wilt of Brinjal in Chhattisgarh, India. Int.J.Curr.Microbiol.App.Sci. 10(06): 575-586. doi: https://doi.org/10.20546/ijcmas.2021.1006.063 